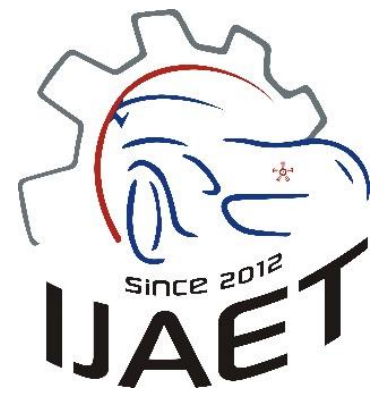

e-ISSN: 2146 - 9067

International Journal of Automotive

Engineering and Technologies

journal homepage:

https://dergipark.org.tr/en/pub/ijaet

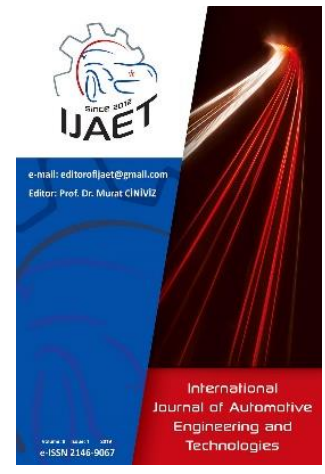

Original Research Article

\title{
Development of a Prototype Hydrogen Vehicle
}

\author{
Ali Cem Yakaryilmaz ${ }^{1}$, Şafak Yildizhan², Arif Emre Aktas ${ }^{3}$, Oğuz Bas ${ }^{4}$, Erdi Tosun ${ }^{5}$, Tayfun \\ Özgür ${ }^{6, *}$, Kadir Aydin ${ }^{7}$ \\ 1, 2,3 and 6 Çukurova University, Faculty of Engineering, Automotive Engineering, Adana, Turkey \\ ${ }^{4}$ Amasya University, Technology Faculty, Mechanical Engineering, Amasya, Turkey \\ ${ }^{5}$ Çukurova University, Faculty of Ceyhan Engineering, Mechanical Engineering Department, Ceyhan, Adana, Turkey \\ ${ }^{7}$ Çukurova University, Faculty of Engineering, Mechanical Engineering, Adana, Turkey
}

\begin{tabular}{l} 
ARTICLE INFO \\
\hline $10000-0001-7977-2959$ \\
$20000-0002-8981-9869$ \\
$30000-0002-6017-9917$ \\
$40000-0003-2301-2306$ \\
$50000-0001-5733-2047$ \\
$60000-0002-8501-2224$ \\
7 0000-0002-1583-9605 \\
* Corresponding author \\
tozgur@cu.edu.tr \\
Doi: 10.18245/ijaet.728407 \\
Received: Apr 29, 2020 \\
Accepted: Nov 17, 2020 \\
Published by Editorial Board \\
Members of IJAET \\
C This article is distributed by \\
Turk Journal Park System under \\
the CC 4.0 terms and conditions.
\end{tabular}

\section{Introduction}

Most of the energy requirements of the world have been met by fossil fuels such as petroleum, coal, etc. Although their frequent usage all over the world, they have lots of undesirable effects as releasing pollutants locally and greenhouse gas effect globally [1].

On the other hand, fossil fuel depletion depending on excessive usage has appeared as a critical concern to be overcome by scientists recently. Researchers intensely work to find alternative energy sources to replace the conventional fuels for the solutions of both economic and environmental issues. On this way, there are various alternative energy sources which are possible candidates for the replacement of petroleum-based fuels such as biodiesel, various alcohols (methanol, ethanol, butanol, dimethyl ether, etc.), SNG (synthetic natural gas), and hydrogen [2].

Hydrogen is outshining alternative resource among of all with its excellent properties. Wider range of flammability levels, high laminar flame speed, and its molecular structure make it proper for direct usage with a dual-fuel mode in internal combustion engine applications. It is a carbon- 
free fuel source which means that there is no hydrocarbon, carbon monoxide, and carbon dioxide emission release towards nature as a result of the combustion process [3].

Besides direct usage of hydrogen in internal combustion engines as fuel, another possible way to reduce the dependency of fossil fuels is passing through fuel cell technology which consumes hydrogen to produce electricity. Fuel cells can be defined as devices which conduce to static energy conversion between chemical reaction of fuels and electrical energy by emitting only water as a product [4]. Literature survey showed that there has been a huge effort on the study of fuel cell technology recently [59].

The main classification of fuel cells with respect to their electrolyte and fuel types can be accomplished as the following: Proton exchange membrane, alkaline, phosphoric acid, molten carbonate, solid oxide, and direct methanol fuel cell [4]. Especially, proton exchange membrane (PEM) fuel cells bring notable advantages like fast start-up, increased efficiency, higher power density, reduced operation temperature, ease, and safe handling [10].

Electric vehicles (EVs) and hydrogen fuel cell electric vehicles (HFCVs) which have no tailpipe exhaust emissions have been prominent lastly. Although some problems are being faced with by searchers with the use of EVs such as high cost, battery charging times, ranges of driving, extra weights generated by battery packages, and infrastructural deficiencies (limited charging stations), HFCVs offer remarkable superiorities over EVs as less time for refueling and more driving distances [11].

Its contribution to the literature is undeniable to the studies conducted in student-centered organizations around the world such as the Shell Eco-Marathon, Formula Student, and TÜBITTAK Efficiency Challenge. Gencer et al. [12] investigated experimentally and numerically analysis of the aerodynamic performance of an electric vehicle. They obtained a drag coefficient of 0.227882 which is smaller than a general passenger vehicle with improved aerodynamics of 0.25 . This is a very useful value, especially for an efficiency competition. Acer et al. [13] conducted a study about the design and optimization of a wheel hub for TÜBİTAK Efficiency Challenge electric vehicles. At the end of the study, they presented a lighter and safer product with $\mathrm{Al}$ 7075 material for the wheel hub. With a lighter wheel hub, they have achieved less energy consumption in the efficiency challenge.

In this study, a prototype hydrogen vehicle was developed by undergraduate students directed by supervisors for the competition organized by TÜBİTAK. A PEM fuel cell was used as a propulsion system according to the advantages supplied by them. The design of the vehicle, shell-frame drawings, and many tests were conducted by the students and academicians withal.

\section{Materials and Methods 2.1. Materials \\ 2.1.1. Motor}

The electric motor that provided the movement of the vehicle was obtained from a local company. The electric motor used to move the vehicle is shown in figure 1.

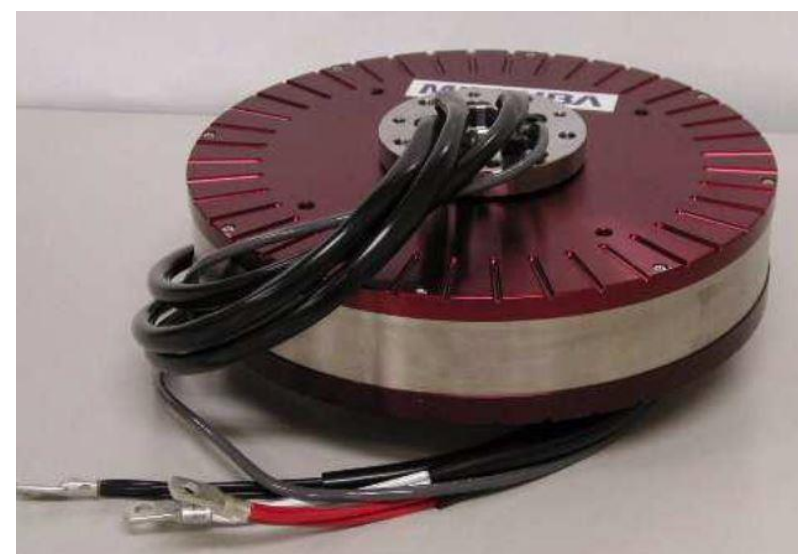

Figure 1. Electric Motor (Mitsuba)

The technical specifications of the electric motor are listed in Table 1.

Table 1. Technical specifications of electric motor

\begin{tabular}{ll}
\hline Motor Code & M0548-II \\
System Outline & $1000 \mathrm{~W} 48 \mathrm{~V}$ \\
Dimensions & $\varphi 262 \mathrm{~mm} \times \mathrm{L} 47 \mathrm{~mm}$ \\
Weight & $7.4 \mathrm{~kg}$ \\
Maximum Power & $2000 \mathrm{~W}$ \\
Maximum Efficiency & $96 \%($ Only Motor) \\
Nominal Rotating Speed & $675 \mathrm{Rpm}$ \\
Rotating Direction & Forward: Left Turn \\
\hline
\end{tabular}

\subsubsection{PEM fuel cell}

A PEM fuel cell that converts the chemical energy of hydrogen into electrical energy is used to produce the electrical energy required for the motor. The PEM fuel cell used to power the electric motor is shown in figure 2 . 


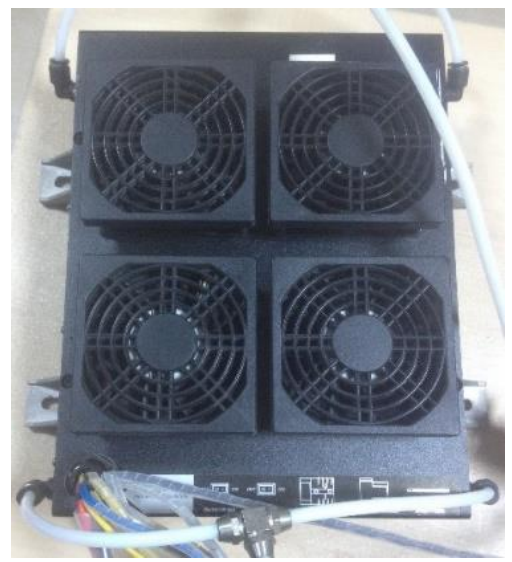

Figure 2. H-1000 XP PEM fuel cell

The technical specification of the PEM fuel cell is given in Table 2.

\begin{tabular}{ll}
\multicolumn{2}{c}{ Table 2. Technical specification of H-1000 XP } \\
\hline Number of cells & 50 \\
\hline Dimensions & 264mm x 203mm x 104mm \\
Weight & Stack less than $4.9 \mathrm{~kg}$ \\
& System less than $6.8 \mathrm{~kg}$ \\
Peak power & $1100 \mathrm{~kW}$ \\
Rated current & $0-33.5 \mathrm{~A} @ 30 \mathrm{~V}$ \\
DC voltage & $25 \mathrm{~V}-48 \mathrm{~V}$ \\
Reactants & Hydrogen and Oxygen \\
Composition & $99.99 \%$ dry H 2 \\
Humidification & Self-humidified \\
Cooling & Air \\
Start-up battery & $12 \mathrm{~V}$ \\
\hline
\end{tabular}

\subsubsection{Material selection for vehicle other parts}

It should be noted that the weight of the vehicle is very important in order to minimize energy consumption since TÜBİTAK competition is not a speed race but an efficiency challenge. Therefore, the materials to be used in the vehicle parts must be light and at the same time strong in terms of safety. In Table 3 selected materials for different vehicle parts are listed.

Table 3. Selected materials

\begin{tabular}{ll}
\hline Vehicle part & Material \\
\hline Chassis & Carbon Fiber \\
Shell & Carbon Fiber \\
Rim & Aluminum 6061 T6 \\
Wheel hub & Aluminum 7075 T6 \\
Axle & Steel 4140 \\
Spindle & Aluminum 7075 T6 \\
Lower and upper swing & Aluminum 7075 T6 \\
\hline
\end{tabular}

\subsection{Methods}

\subsubsection{Design of the vehicle}

All parts of the vehicle were designed with a computer-aided design (CAD) program according to TÜBİTAK competition rules and technical drawings of the full vehicle are shown in Figure 3.
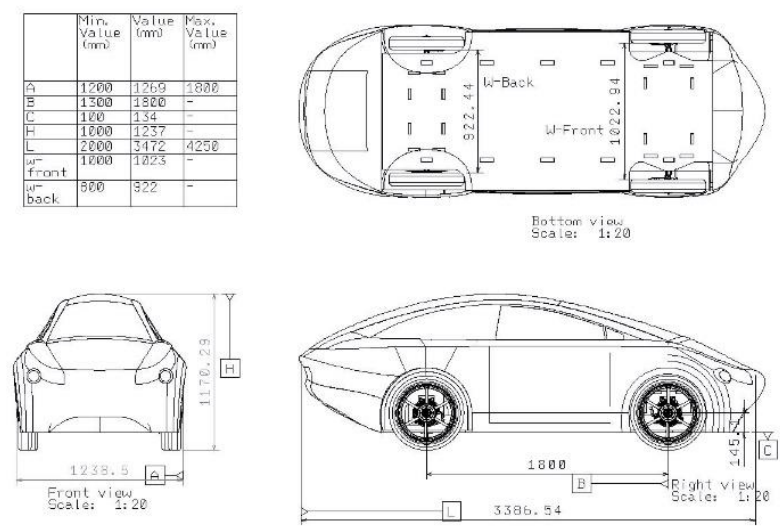

Figure 3. Technical drawings and views of the vehicle

Additionally, roll bars are the critical elements of the design of the vehicle, and drawing of the roll bars was also done with the CAD program, and its representation on the vehicle chassis is given in Figure 4.

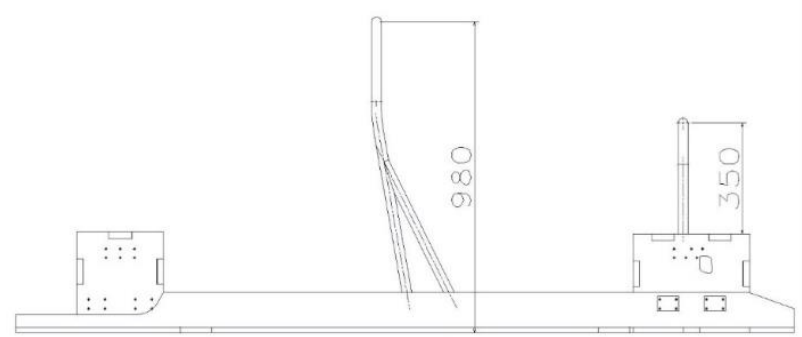

Figure 4. Dimensions of roll bars

\subsubsection{Calculation of drag coefficient}

CFD method was used to calculate the drag coefficient of the vehicle. The following variables were used for analysis and in order to achieve faster analysis results, the vehicle was divided into 2 symmetric parts. The vehicle geometry before starting the analysis is shown in figure 5.

Velocity: The vehicle needs to move approximately $55 \mathrm{~km} / \mathrm{h}$ on the track, therefore the velocity is defined as $15.27 \mathrm{~m} / \mathrm{s}$.

Front Area: $\mathrm{A}=0.66 \mathrm{~m}^{2}$

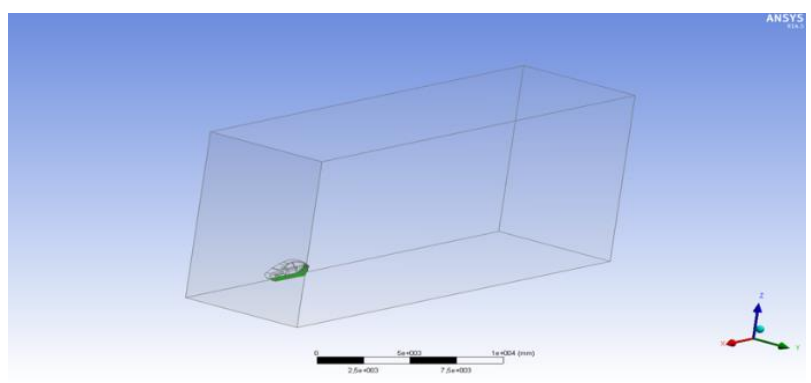

Figure 5. Vehicle geometry before analysis 


\section{Results and Discussions}

\subsection{The shell of the vehicle}

The shell is made of carbon fiber material, which makes the vehicle lighter. The production process was handled by a local company in Adana Metal Industry Site. A male mold was produced to get female molds that are required to produce the shell (Figure 6).

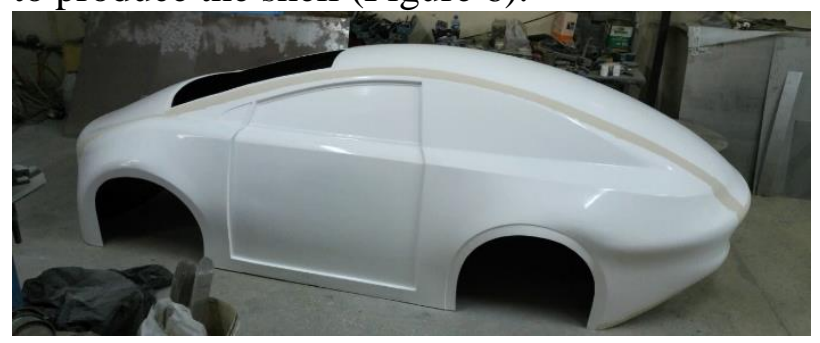

Figure 6. Production of shell

\subsection{Structural analysis of mechanical parts of the vehicle}

\subsubsection{Roll bars}

The required analysis was done with the aid of the static structural module of ANSYS. $1 \mathrm{kN}$ point load was applied between the upper point and lowest point of roll bars according to competition rules.

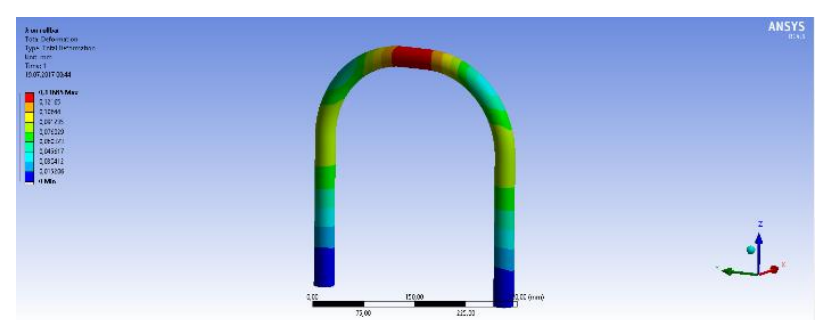

Figure 7. Deformation analysis of front roll bar

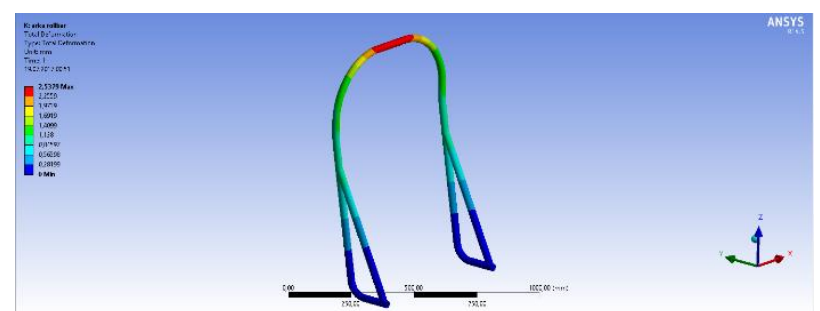

Figure 8. Deformation analysis of rear roll bar

Figure 7 and 8 show that the calculated maximum deformation of front and rear roll bars are $0.13685 \mathrm{~mm}$ and $2.5379 \mathrm{~mm}$, respectively. It was conducted that the displacement level did not exceed the defined limits.

\subsubsection{Other parts}

Table 4 shows the results of the analyses made on the parts of the vehicle exposed to the highest load due to vehicle and driver weights.

The results obtained showed the strength of the produced parts within the desired limits.

Table 4. Structural analysis results of other parts of the vehicle

\begin{tabular}{|c|c|c|}
\hline Part Name & $\begin{array}{l}\text { Deformation } \\
(\mathrm{mm})\end{array}$ & $\begin{array}{c}\text { Equivalent (Von- } \\
\text { misses) Stress (MPa) }\end{array}$ \\
\hline $\operatorname{Rim}$ & 2 & 139 \\
\hline Wheel hub & 0.03 & 23 \\
\hline Axle & 0.16 & 233 \\
\hline Spindle & 0.02 & 64 \\
\hline Lower swing & 0.03 & 37 \\
\hline Upper swing & 0.4 & 75 \\
\hline Lower bracket & 0.003 & 15 \\
\hline Upper bracket & 0.11 & 211 \\
\hline
\end{tabular}

\subsection{Performance tests of PEM fuel cell}

Performance tests were carried out in a laboratory condition due to the long duration of the tests. An electronic load was used to load the PEM fuel cell. It was observed that the fuel cell operates stably in each load range and the graph of hydrogen consumption values is given below.

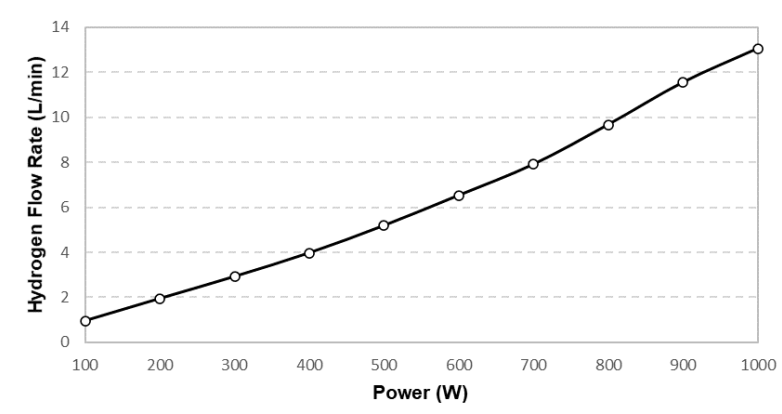

Figure 9. Hydrogen Consumption

In Figure 9, it can be easily seen that the need for hydrogen has also increased with the increase in power at room temperature $\left(25^{\circ} \mathrm{C}\right)$. The fuel consumption can be varied with ambient temperature since high ambient temperature will require higher fan power consumption in order to cool fuel cell and also it will affect the fuel cell stack performance.

Figure 10 shows the consumption of both air and oxygen versus power. Oxygen usage was lower than air usage.

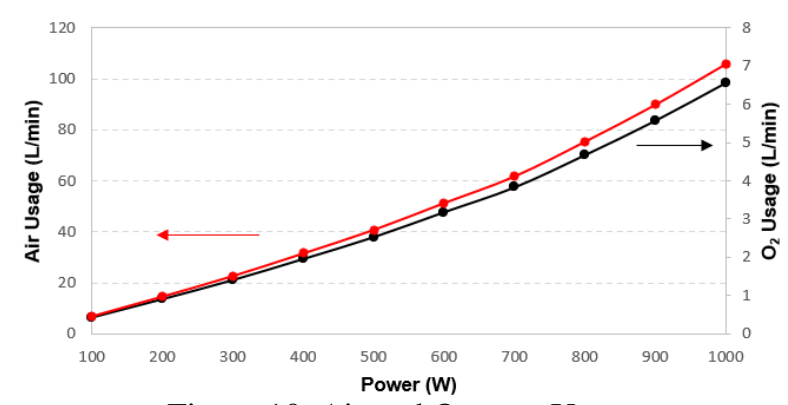

Figure 10. Air and Oxygen Usage

Because PEM fuel cell uses oxygen from the air 
to compound with hydrogen in order to generate electricity. Then remaining air is used to cool the fuel cell stack.

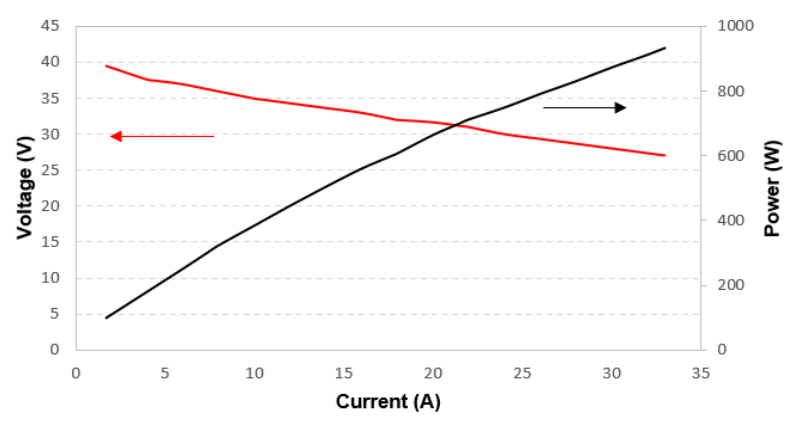

Figure 11. Polarization curve of fuel cell

Figure 11 shows the polarization curve of the fuel cell system operating at the nominal conditions of the fuel cell at normal room temperature. At low power densities, the cell potential decreases as a result of activation losses and at moderate current, the cell potential drops with current due to ohmic losses, and finally, at high current levels, the cell potential drops as a result of concentration losses. Due to all these losses, when the fuel cell is operated in high power bands, this will result in decreases in cell potentials.

\section{Conclusion}

At the end of this project, a two-seater automobile with a weight of about $165 \mathrm{~kg}$ was introduced. The prototype vehicle, created with the help of three-dimensional design and static analysis, and CFD analysis, has been successfully installed in TÜBİTAK efficiency challenge. Targeted studies and outputs were also provided at the beginning of the project and a prototype hydrogen vehicle was manufactured. As a result of CFD analysis, the $C_{d}$ coefficient was calculated as 0.21 and this value was observed to be at an acceptable level for today's standards. The design with a 0.21 drag coefficient reveals the novelty of the study.

For lightweight vehicle, the material selection is the key factor, and it was concluded that light materials such as carbon fiber and aluminum used in this project respond to this low weight requirement.

It was accomplished that the performance results of the fuel cell were sufficient for the vehicle after the tests were completed.

\section{Acknowledgement}

The authors would like to thank the Çukurova
University Scientific Research Project Coordination (FÖA-2017-7503) for financial support.

\section{References}

1. Z. Hbilate, Y. Naimi, and D. Takky, "Modelling operation of proton exchange membrane fuel cells - A brief review of current status", Materials Today: Proceedings, 13, 889898, 2019.

2. A. Ahmed, A.Q. Al-Amin, A.F. Ambrose, and R. Saidur, "Hydrogen fuel and transport system: A sustainable and environmental future", International Journal of Hydrogen Energy, 41, (3), 1369-1380, 2016.

3. N. Khatri and K.K. Khatri, "Hydrogen enrichment on diesel engine with biogas in dual fuel mode", International Journal of Hydrogen Energy, 45, (11), 7128-7140, 2020.

4. A. Kirubakaran, S. Jain, and R.K. Nema, "A review on fuel cell technologies and power electronic interface", Renewable and Sustainable Energy Reviews, 13, (9), 24302440, 2009.

5. S. Obara and I. Tanno, "Study on capacity optimization of PEM fuel cell and hydrogen mixing gas-engine compound generator", International Journal of Hydrogen Energy, 32, (17), 4329-4339, 2007.

6. C. Depcik, T. Cassady, B. Collicott, S.P. Burugupally, X. Li, S.S. Alam, J.R. Arandia, and J. Hobeck, "Comparison of lithium ion Batteries, hydrogen fueled combustion Engines, and a hydrogen fuel cell in powering a small Unmanned Aerial Vehicle", Energy Conversion and Management, 207, 112514, 2020.

7. X. Zhang, M. Luo, W. Dai, C. Yao, J. Wang, D. Huang, and C. Wang, "Automotive fuel cell engine test cell design and its thermal flow analysis", International Journal of Hydrogen Energy, 43, (36), 17409-17419, 2018.

8. N. Baharlou Houreh, M. Ghaedamini, H. Shokouhmand, E. Afshari, and A.H. Ahmaditaba, "Experimental study on performance of membrane humidifiers with different configurations and operating conditions for PEM fuel cells", International Journal of Hydrogen Energy, 45, (7), 48414859, 2020.

9. E. Carcadea, M. Varlam, M. Ismail, D.B. Ingham, A. Marinoiu, M. Raceanu, C. Jianu, L. 
Patularu, and D. Ion-Ebrasu, "PEM fuel cell performance improvement through numerical optimization of the parameters of the porous layers", International Journal of Hydrogen Energy, 45, (14), 7968-7980, 2020.

10. T. Özgür and A.C. Yakaryilmaz, "Thermodynamic analysis of a Proton Exchange Membrane fuel cell", International Journal of Hydrogen Energy, 43, (38), 18007-18013, 2018.

11. P. Ahmadi, S.H. Torabi, H. Afsaneh, Y. Sadegheih, H. Ganjehsarabi, and M. Ashjaee, "The effects of driving patterns and PEM fuel cell degradation on the lifecycle assessment of hydrogen fuel cell vehicles", International Journal of Hydrogen Energy, 45, (5), 35953608, 2020.

12. F. Gencer, Y. Yamaç, M.İ. Aşçı, and R. Gündeşli, "Experimental and Numerical Analysis of The Aerodynamic Performance of An Electric Vehicle", Kahramanmaras Sutcu Imam University Journal of Engineering Sciences, 23, (1), 48-59, 2020.

13. D.C. Acer, Ç. Uzay, N. Geren, and H. Ak1ll,, "Design and Optimization of a Wheel Hub for Lightweight Efficiency Challenge Vehicles", International Advanced Research \& Engineering Congress, 192, 2017. 